\title{
Leading without Followers: How Politics and Market Dynamics Trapped Innovations in Japan's Domestic "Galapagos" Telecommunications Sector
}

\author{
Kenji E. Kushida
}

Received: 19 January 2011 /Revised: 25 March 2011

Accepted: 19 April 2011 / Published online: 3 June 2011

(C) The Author(s) 2011. This article is published with open access at Springerlink.com

\begin{abstract}
While globally successful Japanese industries were able to use their domestic market as a springboard into international markets, Japan's telecommunications sector became decoupled from global markets, trapping Japanese ICT firms in the domestic market. This persistent pattern of leading without followers was not simply the result of misguided technological choices, ill-informed corporate strategies, or insular government standard-setting processes. Rather, the dynamics of competition, shaped and reshaped by political dynamics and regulatory structures, decoupled it from global markets. These dynamics created a "Galapagos effect", in which winning in an isolated domestic market led to losing in global markets. Major regulatory shifts transformed the dynamics of competition since the late 1990s, decreasing the isolation of Japan's telecommunications sector, but some factors pulling it along a proprietary trajectory persist. This paper highlights the dilemma of how to develop beyond a follower status, but avoid becoming a leader without followers.
\end{abstract}

Keywords telecommunications $\cdot$ ICT $\cdot$ Japan $\cdot$ information technology $\cdot$ political economy

JEL Classification L93 $\cdot$ L86 $\cdot$ F50

\section{Introduction}

Japan's Information Communications Technology (ICT) sector presents an intriguing puzzle, yielding lessons applicable elsewhere. Over the past 30 to 40 years, Japanese firms in industries such as automobiles, consumer electronics, precision equipment, semiconductors, and various high tech components have been successful in international markets. Indeed, despite the country's economic malaise from the 1990s, many Japanese

K. E. Kushida $(\bowtie)$

Shorenstein Asia-Pacific Research Center, Berkeley Roundtable on the International Economy (BRIE)

Stanford University, 616 Serra St E301 Stanford University, Stanford, CA 93205, USA

e-mail: kkushida@stanford.edu 
firms continue to be world leaders in various product areas: hybrid automobiles, machine tools, and various high-tech components, to name a few. ${ }^{1}$

In the telecommunications-related portion of the ICT sector, Japanese firms were also leaders in many technologies, products, and markets, but with a critical difference from the sectors above. Japan's telecommunications-related end-products, services, and content firms led the domestic sector towards ever-high levels of sophistication, but the highly developed domestic sector did not lead to prominence in global markets. Time and time again, despite Japanese ICT firms becoming leaders along a particular technological trajectory, global markets shifted in a different direction rather than following Japan's lead. Japanese firms, too far along the previous trajectory, then failed to become major players along the new trajectory. They became caught in a pattern of leading without followers.

This pattern repeated itself across a wide range of telecommunications technologies and markets surrounding telecommunications. In the early 1990s, Japanese firms were on the cutting edge of a set of networking technologies, ATM (Asynchronous Transfer Mode). However, ATM was rendered largely irrelevant with the advent of the Internet, which is based on TCP/IP protocols.

Japan also led the world in deploying a specialized high-speed (at the time) communications network called ISDN (Integrated Services Digital Network). This costly ISDN infrastructure was suddenly rendered almost entirely obsolete in the late 1990s by current broadband Internet access technologies, notably DSL (Digital Subscriber Line), deployed over conventional telephone lines.

From the mid-1990s, Japanese firms developed highly sophisticated and advanced mobile handsets, pioneering a myriad of new high-end features. However, Japanese handsets were largely confined to Japan, and it was Apple's iPhone that spearheaded a worldwide shift towards high performance "smartphones."

Japan also pioneered a dynamic, multi-billion dollar mobile Internet content ecosystem, predating Apple's iPhone platform and content ecosystem by almost a decade. Yet, the entire ecosystem, with a new breed of Japanese entrepreneurs producing profitable and fastgrowing startup firms, was confined to Japan. The iPhone and Android platforms quickly became the dominant global mobile Internet platforms. The list goes on.

What accounts for this persistent pattern of leading without followers in Japan's telecommunications markets? More broadly, what are the implications for understanding the linkages between domestic and international markets? When do we see first mover advantages, and what are the conditions that create first-mover disadvantages? Since these areas in telecom are closely related to services, what can we learn about the nature of services versus manufacturing in international competition?

This paper contends that Japan's leading without followers pattern in telecommunications was not simply the product of misguided government choices, ill-informed corporate strategies, or insular standard-setting processes. I argue that politics and regulatory structures shaped a specific set of competitive dynamics, which in turn shaped the choices of technology, standards, and corporate strategies that ended up isolating Japan's domestic telecommunications market from global markets despite leading in particular technologies and markets. Government choices were constrained by political dynamics and technological uncertainty, corporate strategies were shaped by the domestic competitive dynamics that proved disadvantageous in global markets, and standard-setting, though initially insular, shifted towards adopting global standards, but to no avail.

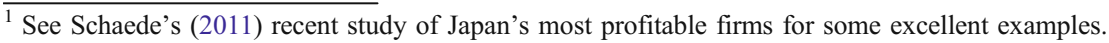


The competitive dynamics center on four key variables: 1) the actors and their resources; 2) the source of technological trajectories; 3) the source of business models; 4) the overall pattern of interactions at the intra-industry and government-industry levels; and 5) the regulatory stance toward global markets. These variables were shaped and reshaped by politics at key critical junctures.

\subsection{The argument in brief}

Political choices at the inception of Japan's telecommunications sector led to a powerful state actor with significant R\&D resources. This state actor set the technological trajectory and shaped the business models for equipment manufacturers. The regulatory focus was on building and operating a reliable communications networks and ensuring universal access across geographic regions - with little attention to global markets. This seemed fine in the early developmental phases of telecommunications worldwide.

In 1985, the state-owned monopoly Nippon Telegraph and Telephone (NTT) was partially privatized and new competitors were introduced, but NTT was not split apart. At the same time, the Ministry of Posts and Telecommunications (MPT) became a bureaucracy capable of industry policy, resulting in both NTT and MPT setting technological trajectories and business models. The sector, largely closed to new entrants and disruptive business models, was characterized by patterned interactions among a stable set of actors. MPT's policy concerns were squarely on domestic development, with little strategic consideration for international markets. Beginning in this period, that Japan's telecommunications sector developed rapidly while becoming decoupled from global markets-leading without followers.

Since the late 1990s, major policy changes have significantly reshaped the dynamics of competition. Although NTT and its R\&D resources were left largely intact, NTT and MPT are no longer the primary setters of technological trajectories. New entrants introduced new, disruptive technologies and business models. They destabilized the entrenched patterns of interaction, sparking price wars between carriers, mounted new challenges to governmentindustry relations, and reshaped relationships between carriers and equipment manufacturers. As a result, Japan's domestic telecom sector has a broader variety of linkages to global markets than ever before. Overall, the danger of new trajectories of leading without followers has decreased. However, some vestiges of the previous era remain; in some areas, mostly infrastructure, the legacy of heavy investments along proprietary trajectories remains substantial.

\subsection{A political economy approach to understanding international competition}

in telecommunications

A political economy approach is particularly useful to analyze market dynamics in heavily regulated sectors, since governments and politics strongly shape the actors and what they compete over - the range of strategic choices available to firms. ${ }^{2}$ The salience of this approach is even more pronounced after the financial crisis of 2007-2008, which revealed that particular types of deregulation fueled the crisis, and during the crisis, many of the key

\footnotetext{
${ }^{2}$ This perspective is derived from the recognition that markets inherently require sustained governmental intervention to function. They are embedded in social norms and rules, not necessarily more so for Japan than the US. Steven K. Vogel labels this the "market-institutional perspective." (Polanyi 1944; Fligstein 2001; Barma and Vogel 2008).
} 
decisions were at the national level (Tett 2009; Sorkin 2009). ${ }^{3}$ The US government's rescue bailouts of AIG, several other Wall Street firms, and even General Motors was unprecedented in scale, decisively influencing the composition of actors and dynamics of competition in finance and automobiles.

At the level of capitalist systems of advanced industrial countries, different political settlements around the world have created a diverse array of institutional configurations and market dynamics (Hall and Soskice 2001; Berger and Dore 1996; Yamamura and Streeck 2003; Zysman 1983; Esping-Andersen 1990). Global competition is often shaped by the interaction of these national market dynamics on a global stage, sometimes mediated by international organizations. Major market disruptions and discontinuous technological breakthroughs that spring onto this global stage are usually the result of concrete developments within a particular national context. (Zysman 2006).

In telecommunications, domestic politics and government policies are especially influential in shaping the actors and their resources, such as R\&D capabilities and funding structures. Most countries began with state-owned monopoly telecom carriers, and political settlements determined the exact nature of privatization, the degree of liberalization, and market rules, such as the terms of competitors' access to incumbents' infrastructure. In the US, for example, judicial decisions split up AT\&T, separating its carrier functions from its $\mathrm{R} \& \mathrm{D}$ labs and equipment manufacturing operations.

Telecommunications is also a prime case where governments influence what actors compete over-the activities to which firms channel their resources to compete-shaping vastly different corporate strategies. Spectrum allocation rules are a powerful illustration. In several European countries, auctions for third-generation $(3 \mathrm{G})$ wireless spectrum led a bidding war, leaving telecom carriers lacking the funds to build out their networks for several years in the aftermath of the IT bubble bursting in 2000-2001. ${ }^{4}$ In Japan, by contrast, spectrum was allocated by the government based on its internal evaluation; carriers spent very little to obtain wireless spectrum, but the set number of licenses available drove consolidation in the industry. $3 \mathrm{G}$ networks were deployed quickly, despite major losses by Japanese carriers in the IT bubble burst as well.

Deep governmental involvement in domestic economies, combined with the diversity of political systems and governmental structures across countries, has resulted in a wide variety of regulatory structures and policy choices across industries-particularly in telecommunications. These differences directly affect the composition of firms, their business model options, and the nature of their competition-hence, the diversity across countries in patterns of innovation, competition, business models, and incumbent carriers' activities. $^{5}$ A political economy approach captures the politics and regulations interacting with national and sectoral dynamics of competition, allowing us to explore the deeper causes of market outcomes, thereby providing a valuable vantage into global competition.

\footnotetext{
${ }^{3}$ For example, the British government refused to ignore its legal requirements hindering Barclays' purchase of Lehman Brothers on the eve of its bankruptcy in a last minute rescue effort involving Wall Street firms and the Federal Reserve.

${ }^{4}$ In global finance, until the 1980s, for example, interest rates on banks and securities were largely regulated; firms therefore did not compete in offering competitive interest rates. In Japan until the early 1990s, business models for highly regulated sectors such as banking and pharmaceuticals entailed allocated significant resources towards wining and dining government officials to gain information.

${ }^{5}$ One thrust of scholarship examines the "fit" between particular technological paradigms and types of innovation with constellations of institutions at the sectoral or national level in various advanced industrial countries (Kitschelt 1991, Vogel and Zysman 2002, Yamamura and Streeck 2003).
} 


\subsection{Roadmap of this paper}

This paper unfolds in three parts. Part I provides an overview of Japan leading without followers in telecommunications by presenting the four technology and market cases. Part II examines the historical origins and evolution of the elements underpinning Japan's dynamics of competition in telecommunications. It traces the market dynamics and firm strategies through the 1990s, as Japan's domestic telecommunications market became decoupled from global markets and entrenched in a pattern of leading without followers. Part III analyzes the substantial transformation in the dynamics of competition since the late 1990 s and early 2000s.

\section{Leading without followers}

First let us expand on how Japan's telecommunications markets became decoupled from global markets, despite becoming highly advanced. Four cases best illustrate the massive opportunity cost for Japanese firms in international markets: 1) ATM switching technology and ISDN networks; 2) digital cellular handsets; 3) the mobile Internet content ecosystem; and 4) high-speed broadband, particularly Fiber-To-The-Home (FTTH).

To begin with, the performance of Japanese firms in international telecommunications equipment markets was never as spectacular as in sectors such as automobiles, consumer electronics, or semiconductors (Fransman 1995). Nonetheless, in the 1980s, Japanese manufacturers did enjoy prominence in areas such as cellular handsets, particularly in the US. The sharp decline of Japan's telecom equipment exports is one indication of the domestic market's decoupling from global markets. Between 1991 and 2001, Japan's share of total OECD communication equipment exports by value fell from $27 \%$ to $8 \%$, with its overall telecommunications trade balance shrinking from approximately $\$ 10$ billion to $\$ 4$ billion (Cole 2006). As we will see, this was not simply a move towards specializing in high-end products or off shoring manufacturing. Let us now turn to the cases.

\subsection{ATM and ISDN: blindsided by the internet and DSL}

First, Japanese firms were at the cutting edge of network technologies and infrastructure of the pre-Internet era. They became highly competent in ATM technology, hailed worldwide until the early 1990s as the future of data networking. Japan also led the world in deploying ISDN communications networks, which boasted a greater ability to carry audio and data transmission vis-à-vis conventional telephone lines. By 2000, Japan had 9.6 million household ISDN lines, while the US, with over twice the population, had 1.9 million (Fig. 1). ${ }^{6}$ However, by 2000, ISDN infrastructure had been rendered obsolete by the advent of DSL, which offered far higher transmission speeds over existing copper telephone wires (ISDN required that existing copper lines be physically replaced.)

Japanese were by no means alone in being blindsided by the advent of the Internetalmost all global incumbent telecommunications firms were caught unprepared as well. Silicon Valley startup firm Cisco Systems and, to a lesser extent, Juniper Networks, took advantage of the situation to move in quickly, capturing dominant global shares of Internet

\footnotetext{
${ }^{6}$ Germany was the only other country that deployed ISDN networks to a similar extent as Japan. See Fig. 1 for the deployment levels.
} 


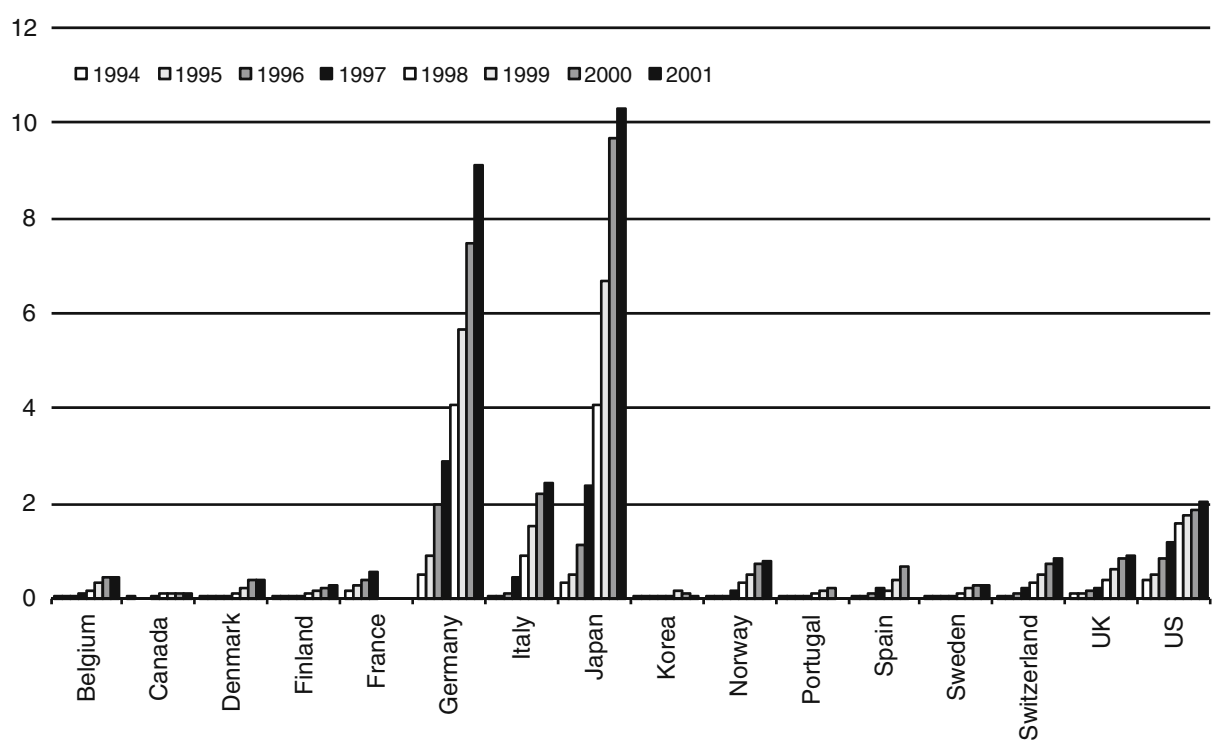

Fig. 1 ISDN deployment in major OECD countries (millions of subscribers)

backbone and switching equipment. However, Japanese firms had been running particularly fast along the ATM/ISDN trajectory, and were especially slow to shift course (Cole 2006).

\subsection{Cellular handsets: the failed resurgence}

Second, from the mid-1990s, Japanese cell phone handsets grew increasingly sophisticated, leading the world in terms of miniaturization and features. ${ }^{7}$ However, even as the domestic market became more sophisticated, Japanese manufacturers' international presence declined precipitously. Their global market share by value dropped from approximately 30\% in 1990 to less than $5 \%$ by 2006 - excluding the joint venture Sony Ericsson-but that $5 \%$ was mostly Japan's domestic market. Sony Ericsson, for its part, actually withdrew from the Japanese market in 2007 to focus on global markets, revealing the extent to which the Japanese market had decoupled from global markets (Kushida 2008). In the US cellular market between 1986 and 1989, Japanese manufacturers had held almost 80\% of the market. However, their shares plummeted to approximately 20\% by 1996 (Funk 2002), dropping precipitously thereafter until by 2006 , all major Japanese firms had withdrawn from the US market.

In the early 2000 s, Japanese manufacturers attempted a comeback into global markets with handsets for third-generation $(3 \mathrm{G})$ cellular services. Japanese carriers deployed $3 \mathrm{G}$ networks in 2001, employing global standards, leading many to expect a resurgence of Japanese handset firms into global markets. However, the bursting of the IT bubble in 2000-2001 delayed 3G deployments around the world by several years. By the time that $3 \mathrm{G}$ became commonplace elsewhere, the Japanese market had surged ahead to develop along a proprietary trajectory, with handset manufacturers competing on the basis of high-

\footnotetext{
${ }^{7}$ Jeffrey Funk documents this trend with data on the precipitous drop in handset size and weight between 1995 and 1998, with Japanese manufacturers' models miniaturizing faster than those of Nokia. (Funk 2002) For an overview the proliferation of features and services by 2004, see Funk (2004) and Mitsuyama (2003b).
} 
end features useful only in the Japanese market. Commonly referred to within Japan as "Galapagos," Japan's cellphones had evolved along a distinct trajectory in an isolated ecosystem; the domestic market was still incompatible with global markets despite using global cellular standards. By 2008, the major manufacturers NEC, Panasonic, and Kyocera had withdrawn from the US and most other international markets. Sony Ericsson held just under 3\% of the US market in 2008 declining to 1.1\% in 2009 (Parker 2010) despite its focus on global markets.

Yet, this was not simply a matter of Japanese manufacturers failing by pursuing high-end products in an era of rapid commodification. The advent of Apple's iPhone spearheaded a new era of "smartphones" that reshaped the dynamics of competition in cellular markets, blindsiding all handset manufacturers and carriers around the world (Kenney and Pon 2011). With a different set of business models than incumbent carriers and handset manufacturers-global and Japanese-Apple's iPhone with its integrated hardware, operating system, and App Store, followed by Google's Android, a smartphone operating system including an App Marketplace distributed for free, shifted the sector to a new trajectory. Indeed, many features of the iPhone, such as the camera and Japanese input system, were initially far inferior to Japanese handsets. Yet, the iPhone became extremely popular in Japan and Japanese manufacturers, again blindsided, are struggling to adapt. ${ }^{8}$

\subsection{Mobile internet content ecosystem: trapped by domestic platforms}

In tandem with Japan's “Galapagos” handsets, Japan's ICT sector developed commercially successful Internet platform services in the late 1990s. Predating Apple's iPhone and App Store by almost a decade, these platforms spawned a robust content ecosystem with annual revenues of almost 3 billion dollars by 2002 and 15 billion by 2009 (DCAJ 2010:203). This content ecosystem produced several notable new, large Japanese firms that dominated Japan's online services markets in areas such as electronic commerce, games, and social networking services (Kushida 2011; MIC 2010). Yet, this content ecosystem was trapped in the domestic market since the platforms were only available (on a large scale) in Japan, a result of the overall failure of Japanese carriers' attempts to introduce them abroad.

The Apple App Store and Android Marketplace introduced global platforms for content and applications. While this creates new opportunities for Japanese content providers to reach global markets, the lost opportunity cost for Japanese firms - in terms of revenue from the platforms, since Apple charges a 30\% share of revenue from App sales, and in terms of the ability to shape the platform to their own advantage-is substantial.

\subsection{High-speed domestic broadband: towards leadership without followers?}

Finally, Japan succeeded in fostering market dynamics that led to low cost, high-speed broadband - the fastest and cheapest worldwide by 2002 (Kushida and Oh 2007). By late $2001,95 \%$ of metropolitan business and residential areas were covered by fiber optic cables to neighborhood telephone lines, and broadband services with throughput of $100 \mathrm{mbps}$ were available at approximately $\$ 60$ per month (compared with 3 to 5 mbps for typical US consumer broadband at similar price points at the time). In mid-2009, NTT raised its FTTH

\footnotetext{
${ }_{8}$ Japan's smartphone market, beginning with the iPhone's introduction in 2008, grew to almost 7 million units in 2010 as the cellular handset market contracted from approximately 50 million in 2007 to 35 million in 2009. (MM Soken, http://www.m2ri.jp) By the second half of 2011, the majority of new offerings were smartphones.
} 
speeds 200 mbps for the same price. An ambitious government plan calls for $100 \%$ household coverage of broadband with speeds greater than $100 \mathrm{mbps}$ by 2014, far exceeding the goals of places such as the US or EU. ${ }^{9}$ Japan is clearly a leader in broadband deployment.

Yet, it is unclear how Japan's extremely high-speed domestic broadband can be put to use for domestic development or industrial competitiveness. While the lack of broadband connectivity can hinder industrial activities and create comparatively disadvantaged regions, the pursuit of extremely high speeds through expensive infrastructure deployments entails its own risks. Domestic innovations and services that depend on extremely high speeds unavailable elsewhere can become trapped in the domestic market. For applications and services to scale internationally, they must often be optimized for slower speeds. Instead, high speed domestic broadband may accelerate the diffusion of "killer" applications from abroad, such as YouTube or Twitter. In attempting to foster domestic development with high-speed networks, policymakers are discovering that it is difficult to facilitate the use of high speed broadband in areas such as healthcare and education, since a variety of laws are involved-more difficult that fostering the network deployment in the first place (Kushida and Zysman 2009).

\section{The development of Japan's leading without followers telecommunications sector (late 1800s-late 1990s)}

In Japan's telecommunications sector, the initial configuration of actors and their resources, the source of technological trajectories and business models, the patterns of interaction among actors, and the policy orientation of the government date back to the inception of the sector itself.

\subsection{The historical origins of actors, resources, and patterns of interaction}

Early government choices in the late 1800 s and early 1900 s put into place the government as a monopoly carrier conducting $\mathrm{R} \& \mathrm{D}$, relying on a closed group of large industrial firms to provide equipment.

As in many other countries, Japan's telecommunications sector began with the government directly operating the networks and services - the Ministry of Communications (MOC). Rather than producing equipment in-house or through a state-owned company, it decided to procure equipment from private enterprise. The government actively participated in creating NEC as a joint venture with Western Electric to receive the latter's technological expertise. NEC grew quickly, becoming the primary supplier of Japan's communications equipment. NEC retained close government ties, hiring former MOC officials into its management ranks.

From the late 1920s, MOC instituted competition among a group of equipment suppliers to decrease its dependence on NEC. The largest of these suppliers became known as the

\footnotetext{
${ }^{9}$ In international comparison, MIC's plan far exceeds that of the US or EU. In 2009, the US FCC announced a bold plan to provide 100 million households with similar broadband speeds (100 Mbps downlink, $50 \mathrm{Mbps}$ uplink), by 2020. It also established a "Connect America Fund" to provide broadband of 4 Mbps as universal service to all households, but no date specified for implementation. In the EU, the Europe 2020 Strategy promulgated in 2010 stipulated broadband access for all EU citizens by 2013, with $30 \mathrm{Mbps}$ or greater speeds for everyone by $2020.50 \%$ or more of those would be $100 \mathrm{Mbps}$ or greater.
} 
"NTT family" firms, including NEC, Fujitsu, Hitachi, and Oki Electronics. ${ }^{10}$ The government aided each firm to develop complex equipment, incentivizing performance by offering larger procurement orders for higher product quality. MOC sanctioned disobedience by threatening exclusion from joint development efforts (Fransman 1995).

This carrier-manufacturer relationship pattern entailing a closed group of suppliers with carrier-led R\&D continued after World War II. MOC was dissolved, and Nippon Telephone and Telegraph (NTT), a fully government-owned monopoly corporation, took over its labs and staff. NTT's massive government budget allocations allowed its procurement to become a de facto subsidy for "family" firms' $R \& D$ in areas beyond telecommunications equipment, such as semiconductors and consumer electronics. Equipment firms, paid on a cost-plus basis, competed for NTT's procurement share based on quality rather than production cost (Anchordoguy 2001). By the late 1970s, NTT's procurement budget was approximately 700 billion yen per year, accounting for up to $40 \%$ of the sales for "NTT family" firms (Prasirtsuk 2001). Although foreign firms had been instrumental in the prewar creation of most "NTT family" firms, multinational corporations were systematically excluded from NTT procurement until the 1980s.

\subsection{Carrier-led technological trajectories and business models}

Since the inception of the sector, the government and NTT determined the technological trajectories and shaped firms' business models. In the 1920s, MOC spearheaded efforts to produce automatic switches domestically rather than relying on imported equipment. It worked closely with NEC, aided other firms' R\&D efforts, and threatened to sanction firms that wanted to rely on imported equipment (Fransman 1995).

NTT continued to set the sector's technological trajectories in the postwar period, illustrated strongly by the case of digital switches. By the 1960s, NEC had become a worldclass producer of analog switches, and by the mid-1980s its R\&D capabilities in this area were prominent globally. However, as the US moved quickly to adopt digital switches, NEC and Fujitsu, waiting for NTT's lead, fell behind decisively in global competition for digital switches. NTT was in no hurry to adopt digital switches in its domestic market, and although NEC and Fujitsu did eventually move ahead to develop digital switches, their need to serve two technologically different markets prevented them from attaining scale or fully concentrating their R\&D efforts on digital switches. When NTT later did eventually adopt digital switching, it chose a different standard from the US, dooming the Japanese equipment manufacturers in the US digital switching market (Fransman 1995). ${ }^{11}$ In sum, as early as the 1960s, NTT's ability to set the technological trajectories and shape domestic firms' business models began to unhinge the Japanese telecommunications market from international markets.

The government at this time was a relatively weak regulator, with NTT at the helm of the sector. In the Allied Occupation government's immediate postwar reorganization of Japan's government, MOC had been disbanded, since it had been a central actor in prewar and wartime government censorship. The bulk of telecommunications staff and resources went to NTT, and telecommunications regulation was added to the postal ministry, creating the Ministry of Posts and Telecommunications (MPT). MPT had little

\footnotetext{
${ }^{10}$ Each of these firms initially relied heavily on foreign technology. For details, see Fransman (1995).

${ }^{11}$ Fransman (1995) notes that NTT's relatively late commitment to digital switches in the late 1970s caused NEC to have to enter the US market with equipment it had not been able to develop and test for the Japanese market beforehand.
} 
telecommunications expertise, with specialists often seconded from NTT. With few regulatory controls over NTT, which received budget allocations directly from the National Diet, MPT was neither a prestigious ministry like the Ministry of Finance (MOF), nor was it focused on international markets like the Ministry of International Trade and Industry (MITI). NTT dominated the sector, and its domestic-oriented mandate was to provide geographically equitable communications services to the domestic market. This situation persisted until 1985.

\subsection{The 1985 political juncture reshaping actors and markets}

In the mid-1980s, a critical political juncture reshaped the actors, resources, and patterns of interaction. In 1985, NTT was partially privatized, though it retained its considerable R\&D capabilities. New competitors were allowed into the sector, ending its monopoly. MPT gained vast regulatory powers, joining NTT in shaping the sector's technological trajectories and shaping firms' business models.

A complicated domestic political debate in the early 1980 s led to the sector's restructuring. A domestic reform debate focused on privatizing state-owned monopolies in sectors including tobacco, railways, and telecommunications, escalating as AT\&T of the US was split apart in 1982. The political struggle over telecommunications involved a long list of actors including NTT, its labor union, politicians in the ruling Liberal Democratic Party (LDP) specializing in telecommunications issues, the opposition Socialist party, Prime Minister Nakasone's administrative reform council, MOF, and MPT. A compromise resulted in NTT's partial privatization, the introduction of limited competition, and a postponement of the NTT breakup issue to subsequent debates (Vogel 1996; Johnson 1989; Kushida 2005).

MPT emerged from this political battle with dramatically strengthened policymaking powers. It shaped the new entrants, carefully limiting the number of new carriers, and restricting foreign entry. It shaped firms' business models through its formal authority to approve pricing, and through informal administrative guidance that limited the scope of firms' business activities; it also segmented the market into areas such as long distance, local, and cellular, and prohibited firms from engaging in more than one area. MPT gained new capabilities to undertake $R \& D$, enabling it to shape certain technological trajectories. MPT was not, however, focused on international markets, legacy of its long institutional history of regulating domestic activities and prioritizing equitable access to communications services. This regulatory structure has been referred to as "controlled competition" (Vogel 1996). It was during this era of "controlled competition," beginning in 1985 and lasting through the late 1990s, that the pattern of leading without followers became most entrenched.

\subsection{How "controlled competition" caused "leading without followers": landline services}

NTT's R\&D resources were intact and its financing mechanisms were considerable, enabling it to set the technological trajectory, invest massively in infrastructure, and dominate manufacturers' business models.

The degree to which NTT dominated NCCs' R\&D resources is illustrated by comparing the 30 R\&D employees of DDI, the first NCC, with NTT's 8500 (Fransman 1995).

NTT also enjoyed powerful legacy mechanisms to raise funds in addition to its monopoly pricing on local communications. For example, it required a 100,000 yen deposit on all new residential and business lines (rarely refunded). With these resources, NTT was 
slow to shift course and led manufacturers along the ATM technological trajectory that turned out to be a dead end (Cole 2006).

The regulatory structure constrained NCCs, providing them neither the incentive to engage in substantial R\&D, nor the ability to formulate international strategies. MPT's tight control over carriers' pricing shaped NCCs' strategies to be only applicable to the domestic market. In long-distance communications, for example, MPT approved price reductions in a "lock-step" pattern, allowing NCCs to lower prices to a certain degree before approving NTT to lower prices to the same level, then approving competitors to lower prices somewhat more (see Fig. 2). NCCs were protected from predatory pricing by NTT, but disruptive new business models were unlikely to be approved if deemed excessively harmful to other carriers by MPT. (Table 1 shows the number of infrastructure-owning carriers licensed). There were few options for NCCs to differentiate themselves from one another. Since MPT compartmentalized the market into specific areas, they were precluded from pursuing global strategies as did British Cable and Wireless, Vodafone, or AT\&T.

NTT itself was prohibited from engaging in international services, as stipulated in the NTT Law that governed its activities, until the law was amended in the late 1990s.

\subsection{Towards Japan's “Galapagos” cellular market}

In the mobile sector as well, NTT's vast resources, in this case combined with MPT's leadership, shaped Japan's cellular "Galapagos."

Long Distance Calls, Tokyo-Osaka (daytime)

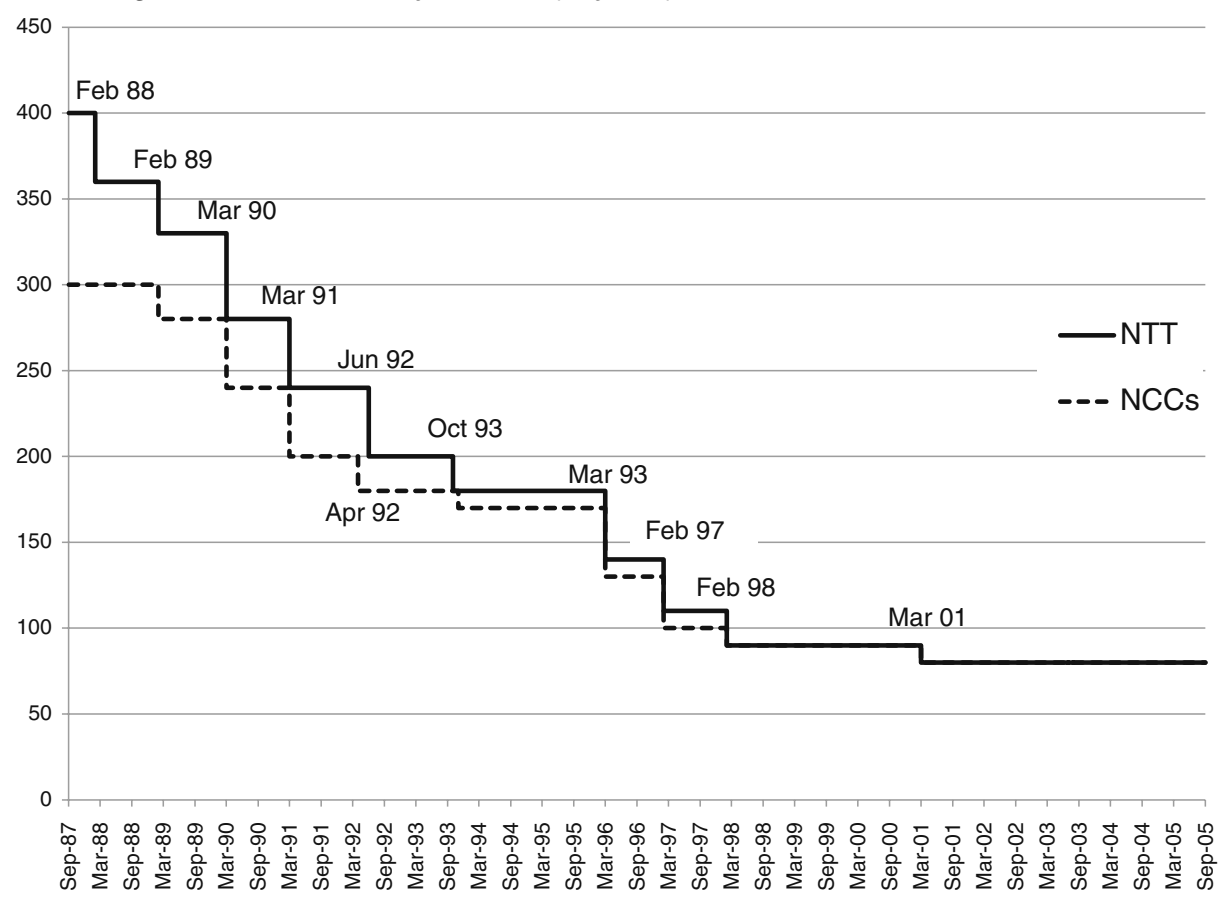

Fig. 2 Changes on NTT's and NCC's call rates (weekday for $3 \mathrm{~min}$ ) 


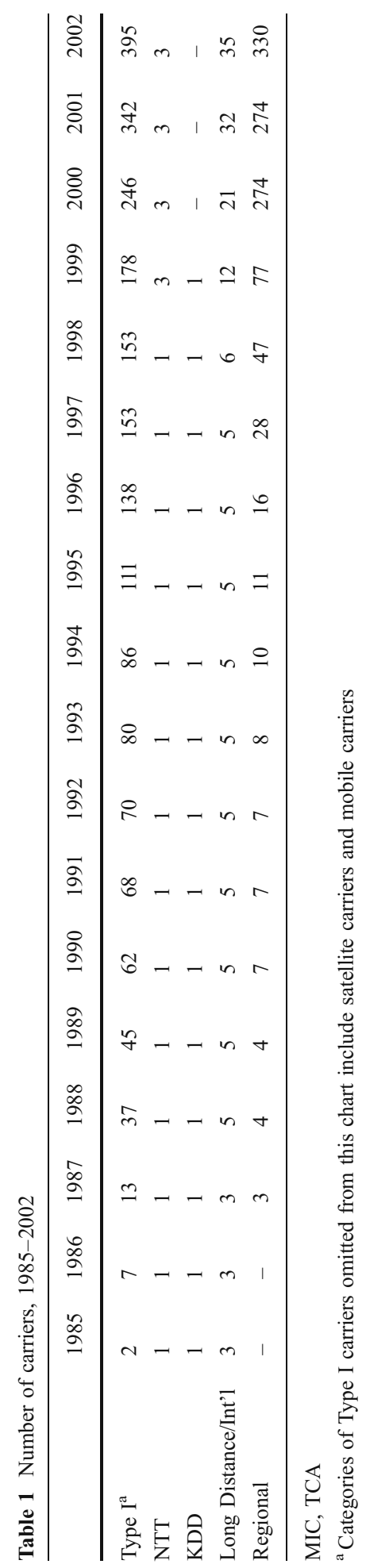


3.6 Mobile handset trajectory: miniaturization at all cost

Throughout the 1990s, NTT led manufacturers to pursue miniaturization and sophistication of cellular handsets, following that trajectory relentlessly until Japan led the world. However, competition for NTT and NCCs' procurement orders pulled manufacturers away from lowering production costs and pursuing global scale.

NTT's relentless pursuit of miniaturization was actually sparked by foreign competition. In 1989, DDI, a cellular NCC that had adopted Motorola equipment introduced Motorola's MicroTAC handset. The MicroTAC was significantly smaller and lighter than the NTT models introduced earlier that year. Especially given the historical moment of 1989, when Japan was at the height of the bubble economy, its electronics firms seemingly poised to take over the world, NTT's president was outraged at coming up short. NTT poured resources into $R \& D$, working with its suppliers and succeeding in introducing handsets, smaller than Motorola's by 1991. NTT kept going, continuing to focus its suppliers towards ever-smaller and sophisticated handsets. NTT had also increased the level of competition between its suppliers by increasing their autonomy over cosmetic design. (DoCoMo 2001). As we will see, the distribution practice of NTT purchasing manufacturers' handsets outright before selling them to customers enabled NTT to prioritize these performance attributes over manufacturers' production cost.

\subsection{Mobile carrier business models of the 90s: DoCoMo leveraging the PDC standard}

Japan's choice of PDC, a proprietary digital cellular standard, was significant in Japan's cellular isolation. This was not simply due to PDC being an incompatible standard from others adopted broadly throughout the world, such as GSM and CDMA. Rather, it was NTT's ability to create dynamics of competition to sustain its advantage in the domestic market that firmly entrenched Japan-specific dynamics of competition, thereby pulling handset manufacturers away from global markets.

PDC was not developed or selected strategically to isolate the domestic market. NTT had begun developing a digital standard in the late 1980s, before it became clear that national cellular markets would grow beyond niche products, with markets linked together through common standards to create global markets. Digital standards used wireless spectrum more efficiently than analog, and as cellular markets grew by the early 1990s, the need to shift to digital became a policy issue. At the time, the GSM standard was becoming popular in Europe, but it required more spectrum-10 MHz-than the $5 \mathrm{MHz}$ allocated to NCCs. NTT's PDC standard was designed to require only $5 \mathrm{MHz}$ per carrier, and there were no other home-grown alternatives, since there was no other concentration of wireless R\&D resources. In the mid-1980s, MPT had been embroiled in US-Japan trade disputes over allocating spectrum to DDI, which deployed Motorola equipment, and MPT wanted to avoid another potential dispute if it reopened the issue of spectrum reallocation. Thus, in 1992, MPT adopted NTT DoCoMo's PDC standard, deployed in 1994 (Kushida 2008).

NTT DoCoMo, a subsidiary of NTT, was spun out in 1991 and received NTT's wireless R\&D labs. This actor and resource configuration resulted from the complex ongoing political battle revolving around MPT, which sought to split up NTT, and NTT, which fought to resist being broken apart. A settlement reached in 1990 spun out NTT's wireless division, still a small part of NTT's business, keeping the rest of NTT largely intact. Many MPT officials at the time worried about DoCoMo receiving NTT's wireless labs, fearing that it would dominate the market, but they could do little since this was a broader political settlement (Kushida 2008). 
DoCoMo's R\&D resources did indeed enable it to shape the market to its advantage, by continually upgrading the PDC standard. By doing so, it was setting both the technological trajectory and shaping the business models of competitors and manufacturers. Although PDC specifications were public, published and approved by the Association of Radio Industries and Businesses (ARIB), additional technical stipulations were required for the commercialization of PDC-based services. Equipment manufacturers were therefore hostage to information from carriers about their operational specifications. Moreover, since only DoCoMo had the resources to modify PDC, manufacturers received frequent updates from DoCoMo's engineers about upcoming updates. Since DoCoMo and its "family" manufacturers had early access to information, they rolled out new services and handsets exactly when ARIB published the new specifications. Many of these modifications dealt with chipsets and circuitry, decreasing or miniaturizing components to enable smaller handsets. DoCoMo therefore enjoyed a lineup of handsets that were smaller and more advanced than those of competing carriers, ${ }^{12}$ and "NTT family" handset manufacturers enjoyed a competitive edge over others, such as Kyocera, Toshiba, Sanyo, Sony, and the foreign manufacturers such as Nokia and Motorola.

DoCoMo further shaped the business models of "family" handset manufacturers by prohibiting the latter from selling their DoCoMo handsets to others for several months. ${ }^{13}$ Even for component manufacturers, development projects between DoCoMo and its manufacturers usually included non-disclosure agreements signed by components manufacturers, prohibiting them from disclosing details or selling the new components to non family handset manufacturers, typically for 6 months. Since new models appeared almost every month, DoCoMo suppliers held an advantage, pushing non-family manufacturers to differentiate themselves in attributes other than those conferred by updates to PDC, such as design and handset feature.

NTT's traditional procurement practices further shaped carrier-manufacturer relations, creating manufacturers' Japan-specific business models that hindered the latter's potential global strategies. Carriers purchasing handsets from manufacturers became the standard industry practice, entailing large commissions to retailers. Competition among carriers escalated commission levels, which reached over $70 \%$ of the cost for top class handsets, and virtually $100 \%$ for other models. Similar dynamics occurred elsewhere in the world, especially after the turn of the century, but Japanese carriers' subsidies reached 300-400 dollars by the mid-1990s, without multiple year binding contracts. This put them on a different footing from global markets, where manufacturers like Nokia and Motorola, which focused on lowering production costs to sell handsets directly to consumers around the world.

Frequent updates to PDC and fast cycles of handset renewals prevented handset manufacturers from attaining large scale production, since their efforts were focused on obtaining procurement orders based on design and new features. ${ }^{14}$ The domestic market became a steady source of revenue for manufacturers, but their R\&D resources were taxed by the constant demands from carriers for new high-end features and frequent handset model updates. The short lifecycles of handsets further precluded an automatic spillover from the domestic market to global markets (Kushida 2008).

\footnotetext{
${ }^{12}$ Funk (2002) documents how size differentials between DoCoMo and non-DoCoMo handsets remained significant for several years until around 1998.

${ }^{13}$ This practice led to an investigation by the Japan Fair Trade Commission in April, 1999 (Yuasa 2000).

${ }^{14}$ Each handset model was built from the ground up, rather than sharing platforms across models, as Nokia or automobile manufacturers build their products.
} 
3.8 PHS: Japan's proprietary mobile services driven by MPT's industrial policy

MPT's rise as a ministry capable of shaping the sector's technological trajectories accelerated the isolation of Japan's mobile sector by orchestrating the creation of the Personal Handyphone System (PHS). PHS services were the brainchild of MPT, which assumed in the early 1990s that conventional cellular services would remain prohibitively expensive for ordinary consumers. Technologically simpler than cellular services, PHS influenced the dynamics of competition in Japan's mobile sector by offering smaller and cheaper handsets with clearer voice communications, higher data transmission speeds, and lower service prices. As cellular carriers scrambled to meet the competitive challenges from PHS, they intensified efforts that ended up pushing Japan's cellular sector along its proprietary trajectory.

MPT spearheaded the R\&D into PHS, conducting field experiments and setting the technical standard. MPT shaped the PHS carriers by directing existing cellular carriers to obtain licenses, resulting in three consortia and joint ventures. ${ }^{15}$ Foreign firms were strategically kept out of the standard-setting process, with the PHS specifications becoming public at the same time services began commercial operations in 1995 (Funk 2002).

PHS markets grew rapidly, becoming a major threat to cellular carriers, forcing them to concentrate their efforts on lowering service prices, increasing voice quality and coverage, miniaturizing handsets, adding extra functionality, and increasing commissions to lower consumer upfront costs. In the end, cellular services and handsets caught up and overshadowed PHS, but PHS indisputably accelerated the trajectory of miniaturization, sophistication, and a push towards heavily subsidized high-end handsets-"Galapagos."16

\subsection{Japan's cellular “Galapagos": cellular internet platform services and ecosystem}

Arguably the most dramatic case of Japan's telecommunications sector leading without followers was its pioneering innovation of commercially successful cellular Internet platform services. These platform services spawned a robust mobile content market, and an array of advanced cellular handsets co-evolved with the platforms. This ecosystem of platforms, content, and handsets developed rapidly from the late 1990s, but the entire ecosystem was confined to Japan's domestic market.

While politics and government policies did not directly create Japan's cellular Internet platforms, the latter grew out of the policy-shaped proprietary market dynamics. Since the unintended consequences of government policy provided DoCoMo with decisive advantages in Japan's cellular markets from the mid-1990s, competitors desperately sought new strategies. At the same time, by the late 1990s PHS service providers, facing declining subscription levels, turned to Short Message Services (SMS). The popularity of SMS revealed significant latent demand for such message-based services (Suzuki et al. 2005). In

\footnotetext{
${ }^{15}$ They included NTT Personal Communication Network (a joint venture between NTT and its wireless subsidiary, NTT DoCoMo), DDI Pocket (a subsidiary of DDI), and Astel (a consortium including Japan Telecom and KDD)

${ }^{16}$ PHS services eventually declined in competitiveness vis-à-vis cellular handsets and services, as cellular carriers and manufactures closed the gap in size, usability, and price. Moreover, NTT was able to charge predatory prices to PHS carriers dependent on its public network infrastructure, squeezing the profits of PHS carriers. After peaking in 1998, the number of PHS subscribers declined, leaving only one in the market. Having essentially given up on PHS technology, manufacturers opened the intellectual property to Chinese carriers, which precipitated a boom in regional Chinese cities - an interesting story in and of its own (Suzuki et al. 2005)
} 
this industry environment, the cellular carriers began a race to develop cellular Internet services of some form. ${ }^{17}$

Japanese carriers, particularly DoCoMo, pioneered a new Internet connection service business model that became commercially successful, widely lauded by the early 2000 s by business analysts, scholars, and market research firms such as Gartner (Beck 2003; Ratliff 2002; Murase 2003; Mitsuyama 2003). Most analyses credit DoCoMo, but in fact the Japanese cellular industry environment that focused carriers on this search of a new cellular Internet business model is an underappreciated, but critical driver (Kushida 2010).

The three nation-wide cellular carriers pursued independent technological paths, and DoCoMo actually lagged behind for much of the race. ${ }^{18} \mathrm{~J}$-Phone was the first to roll out a cellular information service, Sky-walker, in late 1997, taking DoCoMo by surprise. DoCoMo's president at the time, Koji Ohboshi, was reportedly furious about falling behind in the race. When J-Phone rolled out an early, text-only version of its cellular Internet service in December 1998, DoCoMo again lagged. ${ }^{19}$

In early 1999 DoCoMo introduced its $i$-mode service, with an innovative business model involving profit-sharing with third party content providers. $i$-mode and the others were "open-but-owned" platforms-open in that third parties could create content independently, but owned by carriers who controlled and charged for the gateway to the content (Vogel and Zysman 2002). i-mode subscription fees were low, at 300 yen per month. ${ }^{20}$ A portal menu listed "official" content approved by the carrier. "Official" content providers could charge subscription fees ranging from 100 to 300 yen, integrated into carriers' monthly cellular billing statements. Carriers took a percentage of this monthly fee, initially 9\% (Funk 2002). This solved the payment problem for content providers, particularly since credit card use in Japan was relatively low at the time. "Unofficial" content could be accessed anywhere on the Internet if written in a proprietary simplified form of the html language used for websites. Carriers charged users for data transmissions, decreasing their incentive to make the platform closed since they benefitted from traffic to "unofficial" sites as well. Internet email quickly became the first "killer application," providing most Japanese consumers' first experience with "always on" Internet and email access.

DoCoMo pioneered this business model, and its competitors followed closely with equivalent business models. Their use of different underlying technologies and networks to quickly roll out similar services reveals their focus on this race. ${ }^{21}$

Japan's close carrier-manufacturer ties enabled carriers to introduce their Internet platform services concurrently with an array of compatible handsets. This solved the chicken and egg problem found in other countries, in which carriers and manufacturers waited for each other to make the first move (Funk 2001). The popularity of Internet

\footnotetext{
${ }_{17}$ They were also following a worldwide consensus that this would be the next direction for mobile services.

${ }^{18}$ Tokyo Digital Phone (later J-Phone) went to a research lab in Keio University; IDO (later KDDI) joined the Wireless Access Protocol (WAP) forum assembled by the American firm Unwired Planet; and DoCoMo strengthened ties to Access, a Japanese startup software company.

${ }^{19}$ Kontentsu kakumei no kishu tachi: "kokusaikijun" de dokomo ni taikou. 2003. Nihon Keizai Shimbun, October 8, 5.; Kontentsu kakumei no kishu tachi: shanai benchaa, nankan toppa. 2003. Nihon Keizai Shimbun, October 9, 5.; Kontentsu kakumei no kishu tachi: shameru de onnagokoro tsukamu. 2003. Nihon Keizai Shimbun, October 10, 5.

${ }^{20}$ Approximately 3 USD at $\$ 1=100$ yen.

${ }^{21}$ DoCoMo introduced i-mode in February 1999, KDDI followed with EZWeb that April, and J-Phone with J-Sky in December. DoCoMo constructed an entirely new, nationwide packet-switched network while KDDI used a CDMA-based Motorola equipment network, and J-Phone used a circuit switched PDC network from NTT family firms.
} 
platform services drove carriers' revenue sources towards income from data packet transmissions. For example DoCoMo derived $10 \%$ of its monthly average revenue per user from i-mode in the first quarter of 2001, which grew to almost $25 \% 2$ years later. This was a business model departure from other advanced industrial countries.

Since the cellular Internet platforms existed only in the domestic market, the content ecosystem and advanced handsets were trapped in the domestic market. DoCoMo did attempt to take $i$-mode internationally, purchasing minority stakes in several overseas carriers, including AT\&T Wireless in the US, KPN Mobile in the Netherlands and carriers in other, mostly small European countries. However, DoCoMo was unable to influence its partners to adopt the entire ecosystem of platform services, handset manufacturers and content providers. In the case of AT\&T Wireless, DoCoMo failed to convince it to adopt DoCoMo's $i$-mode variant as an open platform. Moreover, when the IT bubble burst in the early 2000s, DoCoMo sustained massive equity losses-812 billion yen in the fiscal year 2001. DoCoMo then shifted to a cautious licensing strategy, mostly in Europe, but the dearth of $i$-mode capable handsets prevented widespread adoption (Mitsuyama 2003).

In the meantime, as cellular Internet services continued to grow rapidly in the Japanese market, reaching 67 million out of 80 million cellular subscribers by December 2003 (TCA), Internet service quickly became the focal point of competition among carriers. The sector literally began to take on a Galapagos-like appearance, with exotic new shapes, sizes, and features of cellphone handsets not found elsewhere.

In this isolated but highly competitive domestic market environment, DoCoMo was increasingly a follower. J-Phone was the global pioneer of camera-embedded phones in 2001; a major service innovation was its function enabling users to email pictures. J-Phone had worked closely with Sharp, a manufacturer without strong ties to DoCoMo. It took DoCoMo approximately a year to offer similar services and orchestrate manufacturers' introduction of camera-embedded handsets. KDDI was first to market with downloadable songs, "chaku-uta," which became immensely popular, logging 5 million downloads 16 months after its introduction in late 2004, closing in on the number of CD singles sold in mid-2006 (Masuno 2006). DoCoMo was again a follower in this area, but led in other areas such as micropayments through IC card-embedded handsets and downloadable Java applets to run small software applications. The industry catapulted towards new services, such as the capability to display digital television broadcasts, biometric scanners to protect access, and various GPS-enabled applications and services before they became standard elsewhere. In sum, despite adopting a global standard and attempting to internationalize its services, the dynamics of competition in Japan's cellular industry propelled it along a proprietary trajectory.

\section{Regulatory shifts and market disruptions: moving beyond leading without followers?}

Regulatory reforms in the late 1990s, consisting of a combination of deregulation and reregulation, opened the way for major shifts in the competitive dynamics of Japan's telecommunications sector. The actors, their resources, the sources of technological trajectories and business models, as well as the patterns of intra-industry and government-business interactions all underwent substantial shifts. A new regulatory focus on international competitiveness and global markets led to policies deliberately aimed at reshaping the domestic sector. Yet, several continuities remained-most importantly NTT as a cohesive actor with considerable, though diminished, financial resources, and extensive $\mathrm{R} \& \mathrm{D}$ resources. 


\subsection{The regulatory "regime shift"}

Major regulatory shifts in the late 1990s embodied a change in MPT's orientation from ex ante competition management to governing the industry on an ex post basis (Kushida 2006). The shifts entailed deregulation, relaxation of rules, and re-regulation, meaning the creation and implementation of new rules and organizations. ${ }^{22}$ The regulatory shifts occurred over several years, and in piecemeal fashion. The deregulation was driven by a normative shift within the ministry, supported by the political environment (Kushida 2011). It was not simply the result of pressure from business groups, foreign governments, or international organizations.

In several steps starting in 1998, MPT lowered the entry barriers for new firms and allowed foreign ownership of network infrastructure. MPT also relaxed its control over pricing and decompartmentalized the sector, freeing carriers to pursue multiple business areas. $^{23}$

\subsection{A new cast of actors: merged, new, and foreign}

A political agreement between MPT and NTT in 1995 led to a settlement that reshaped NTT into a holding company (Kawabata 2006; Vogel 2000). Overall, however, the company retained a high level of coherence. For example, it transferred excess personnel from the loss-making local carriers NTT East and NTT West to the profitable NTT DoCoMo. Importantly, it retained its $R \& D$ capabilities and the capacity for long-range planning.

The decompartmentalization of the sector paved the way for consolidation among NCCs. In 2000, a merger among several NCCs (KDD, DDI, and IDO) created KDDI, the largest competitor to NTT in landline, wireless, broadband, and international services. ${ }^{24}$

Deregulation also allowed new entrants into the sector, many of whom introduced new technologies, disruptive business models, and new patterns of interaction, as shown later. New entrants included startup firms as well as foreign multinational firms.

In 2001, a sequence of events involving Vodafone, a British carrier with a major global presence, revealed how far deregulation had opened the Japanese telecommunications market. Vodafone purchased a major NCC, Japan Telecom, which owned one of the three nationwide cellular carriers, J-Phone. It was the largest inward M\&A deal in Japan's history at the time. Vodafone split off and sold Japan Telecom's landline division to US investment fund Ripplewood, who in turn sold it to Softbank, a new entrant into the sector. Softbank's acquisition of major network infrastructure in a single transaction was unprecedented in the sector. In 2006, Vodafone exited Japan (at a profit), selling its mobile operations and infrastructure, again to Softbank, at the time Japan's largest leveraged buyout (Kushida

\footnotetext{
${ }^{22}$ Vogel (1996) differentiates between deregulation and reregulation as components of liberalization, an increase in the overall level of competition.

${ }^{23}$ See Fuke (2000) for an overview. By 2003, the ministry had abolished its entire regulatory apparatus for classification, registration and notification.

${ }^{24} \mathrm{KDD}$ had been a government-owned corporation monopolizing international communications until its privatization in 1984. After deregulation in 1998, it was allowed to enter other areas, and was no longer a designated special corporation governed by the KDD Law, which was abolished that year. It merged with Teleway Japan, an international service firm with Toyota as the primary investor. DDI was the first NCC set up in 1985, with a set of cellular subsidiaries in Western Japan. IDO was a cellular NCC with major investments from Toyota.
} 
2010). Therefore, in sharp contrast to the stable actors of the 1980s and 1990s, the 2000s saw not only one of the three nationwide cellular carriers becoming a foreign firm, but by 2006, a completely new entrant had utilized advanced financial tools to become a nationwide landline and wireless carrier. Softbank, unlike the original NCCs, was neither a subsidiary nor close affiliate of Japan's major industries firms; it was a new breed of independent Japanese startup firm.

\subsection{New technological trajectories: the internet, broadband, and mobile disruptions}

Starting with the coming of age of the Internet, NTT and MPT began to lose their ability to define the sector's technological trajectory to new entrants, foreign and domestic. First, as the Internet became widely popular around the world in the mid-1990s with the advent of the World Wide Web, a new market of Internet Service Providers (ISPs) grew rapidly in Japan. Many would have preferred to buy from familiar Japanese equipment manufacturers such as NEC or Fujitsu. However, the Japanese manufacturers, in pursuing ATM, lacked a product lineup of backbone equipment and routers based on the Internet's TCP/IP protocols, a fundamental different design paradigm. As it did most everywhere else, Cisco took the opportunity to enter Japan and dominate the market for Internet equipment. Japan's router market grew from 55 billion yen in 1995 to 202 billion yen in 2002, and Cisco's share between 1999 and 2001 was estimated at over 80\% for high end and over $70 \%$ for mid-range routers. ${ }^{25}$

New entrants also spearheaded the introduction of DSL, a technology that disrupted NTT's plans to utilize ISDN until it completed a nationwide fiber-optic network rollout. Pioneered by startup firm Tokyo Metallic, others quickly followed and DSL rapidly grew in popularity-eventually forcing NTT to delay its fiber strategy and deploy its own DSL services (Kushida 2011). DSL was disruptive to NTT not only because it offered far higher transmission speeds than ISDN, but because it could be deployed over conventional copper lines to offer flat-rate unlimited access. This challenged NTT's ISDN business model to charge per minute, and moreover, NTT had to physically restore copper wires to the prospective DSL subscribers who had already switched to ISDN.

In mobile, the advent of the iPhone in 2007 and the rapidly expanding market for "smartphones," decisively shifted the technological trajectory away from Japan's high-end but proprietary "Galapagos" handsets and cellular Internet platforms. By 2009, the iPhone held over $70 \%$ of Japan's fast growing smartphone market, with Taiwan's HTC in second with 11\%, and Toshiba and Canada's Research In Motion following them with single digits. While the initial iPhones had a significant proportion of Japanese components, the technological trajectory in terms of design and software were clearly led by Apple.

\subsection{New sources of business models: new entrants, NCCs, foreign firms at center stage}

New entrants introduced new, disruptive business models unthinkable under the "controlled competition" regulatory regime. We already noted how a few DSL startups brought disruptive technologies and flat-rate, high-speed broadband to Japan. After the government actively strengthened regulations over NTT, improving the terms for DSL startups to utilize

\footnotetext{
${ }^{25}$ Cisco does not release Japan-specific market shares. Estimates from the Fair Trade Commission of Japan. (Tanaka and Murakami 2003). By the early 2000s, Cisco and Juniper enjoyed approximately $80 \%$ of the global market for Internet routers and switching equipment.
} 
NTT's infrastructure and lowering leasing fees, Softbank entered the business and delivered a game-changing price shock; in August 2001 it offered DSL at half the prevailing price. This created headlines and raised the profile of DSL, leading to its rapid growth. DSL subscribers grew from just under 300,000 in the months preceding Softbank's DSL service, to 8.2 million by June 2003. Observers at the time, including ministry officials, were concerned that Softbank's strategy was reckless and even irresponsible, as it initially incurred major losses. ${ }^{26}$ Softbank's sales tactics were particularly aggressive as well, employing temporary workers to canvass metropolitan areas with temporary booths that gave free 100 plus dollar value DSL home routers to new subscribers.

Softbank followed its DSL price shock with an attack on Japan's conventional telephone pricing. In early 2002, it began bundling free telephone-replacement Voice over Internet Protocol (VoIP) with its DSL subscriptions. VoIP technology sends voice signals over the Internet, circumventing the traditional telephone switching network, but most popular forms, such as Skype, require a computer on one end. Softbank's service was aimed directly at replacing NTT telephone subscriptions, entailing users connecting their existing telephone sets into Softbank's home DSL router. Softbank allowed free unlimited calls between Softbank IP telephony subscribers, and extremely low rates for international calls - the first time mainstream Japanese consumers experienced flat-rate telephony. ${ }^{27}$ VoIP then received regulatory support in the form of telephone number allocations, becoming a valuable lever for DSL, and later, FTTH broadband services provided by NTT's competitors.

Japan's new market for FTTH services was strongly shaped by the low priced DSL market. Usen, another new entrant, pioneered Japan's FTTH in 2001, at prices comparable to DSL before the Softbank's price shock-about half of what NTT had planned to charge. While the sudden, explosive growth of DSL delayed Usen's plans for a broader FTTH rollout, the availability of extremely high speed FTTH forced NTT to offer its own FTTH at similarly low rates.

While the Japanese government's failure to completely break up NTT provided it the financial strength to deploy FTTH nationwide (Ida 2009), MPT's classic industrial policy measures since the early 1990s actually supported competitors' fiber deployments. Lowinterest loans through the Development Bank of Japan, and subsidized interest payments through a semi-public entity, the Telecommunications Advancement Organization, were among the measures that facilitated building of NCCs' own fiber networks. ${ }^{28}$ Thus, by the time that DSL was spreading rapidly in the early 2000s, NTT and several NCCs had built extensive fiber networks, but their service business models, offering low fees and searching for value through other services, were shaped by Softbank's unexpected DSL price shocks.

In mobile as well, NTT and MPT no longer shaped the sector's business models. PHS services, suffering market shrinkage as cellular services took over, shrank to one carrier. However, this carrier, DDI Pocket, began offering flat-rate mobile data services, the first of its kind, in 2001. In 2003, KDDI pioneered flat rate data plans for cellular Internet platforms, forcing DoCoMo and Vodafone to follow suit in 2004. This undermined a major revenue driver of the original DoCoMo-pioneered business model-charging for data traffic.

Competitors also challenged the DoCoMo-pioneered revenue model for mobile Internet platforms of relying heavily on subscriptions to "official" content. In mid-2006, KDDI

\footnotetext{
${ }^{26}$ By 2005 Softbank's DSL business became profitable.

${ }^{27}$ For details, see Kushida and Ogata (2007).

${ }^{28}$ By 1999, over 75 billion yen worth of loans had been allocated.
} 
began including a Google search bar on its portal, leading DoCoMo and Softbank (which had bought Vodafone's operations) to partner with other search engines such as Yahoo. By early 2007 , an estimated $70 \%$ of mobile Internet sites were "unofficial" sites, a growing proportion of which were supported by advertising rather than subscription fees. ${ }^{29}$ Finally, by 2008 , it was clear that the iPhone and Android application markets would become the dominant global mobile content platforms, and the entire content ecosystem has begun rapidly shifting direction to ride these global platforms.

\subsection{New patterns of interaction: price wars, litigation, and manufacturer consolidation}

New entrants and the shifting dynamics of competition introduced new patterns of intraindustry and government-business coordination.

In intra-industry coordination, the price shocks and new technologies by new entrants were a radical departure from the government-managed lock-step price decreases during the "controlled competition" era. The telecommunications ministry also removed itself from the center of intra-industry negotiations over issues such as interconnection fees by creating the Dispute Resolution Commission, an organization located within the ministry, but designed to resolve disputes between firms in a publicly open fashion. Its first ruling were against NTT in cases brought by DSL startups.

In government-business relations, the most dramatic shift took the form of litigation against the government. In 2003, a group of five carriers, led by KDDI, sued the Ministry of Internal Affairs and Communications (MIC-which had taken over telecommunications regulation from MPT) in 2000. It was the sector's first administrative litigation, and the plaintiffs included Japan Telecom, then majority owned by Vodafone, startup firms Powerdcom and Fusion Communications, and British-Japanese joint venture Cable \& Wireless IDC. The direct issue was MIC allowing NTT to raise its telephony interconnection rates, but the lawsuit was as importantly a warning against nascent political maneuvers, hinting that MIC might allow NTT to fiber network access rates critical to FTTH providers. While the case was ultimately dismissed 2 years later, if signaled to the government that firms would no longer tolerate politicized or opaque policymaking (Kushida 2010).

In 2004, Softbank launched the sector's second administrative litigation as it attempted to obtain wireless spectrum. MIC's allocation of the $800 \mathrm{MHz}$ spectrum band was underway, and Softbank called for an injunction, calling for new, publically open allocation methods. Softbank's president criticized MIC-carrier relations, contending that their negotiations behind closed doors went hand in hand with incumbents hiring retired MIC officials. Two months later, Softbank rescinded the lawsuit when MIC convened a study group to examine the issue. While the $800 \mathrm{MHz}$ allocation proceeded as planned, the following year three new entrants, including Softbank, were allocated licenses in the 1.7 GHz spectrum range. In another unprecedented move, Softbank returned the spectrum license upon acquiring Vodafone's Japan operations (NikkeiCommunications 2005). Since MIC had given up most of its powerful discretionary powers to shape the sector, firms were freer to openly challenge its decisions and processes.

In the mobile sector, intra-industry consolidation began to shift as carriers' dominance over handset manufacturers eroded and a wave of consolidation swept through handset

${ }^{29}$ See Keitai Denwa: Sony, Docomo muke tettai [Cellular phones: Sony withdrawing from supplying DoCoMo] 2008. 
manufacturers. By the mid 2000s, Japan's cellphone industry approached saturation, growth slowed, and manufacturers' profitability declined precipitously. In March 2007, the total profits of carriers was 1.3 trillion yen, while that of the 11 handset manufacturers combined was only approximately 0.3 trillion. $^{30}$ This led to demands by manufacturers for independent branding, and traditional "NTT family" relationships and carriermanufacturer grouping broke down. Table 2 shows the groupings of carriers and manufacturers in 2006. NTT family firms Panasonic and Fujitsu supplied DoCoMo exclusively, and NEC supplied DoCoMo and Vodafone, but not DoCoMo's biggest rival, KDDI. Conversely, non-NTT family firms Sony Ericsson, Toshiba, and Casio supplied KDDI, but not DoCoMo. In 2007, however, Panasonic and NEC began offering handsets to KDDI and Softbank. Around the same time, Sharp introduced handsets under its own brand, rather than that of the carrier, to DoCoMo-which had never procured from Sharp before-and KDDI. ${ }^{31}$ Sharp had leveraged the extreme popularity of its "Aquos" brand handsets, optimized for viewing digital television, in the slowing market. Table 3 shows how the carrier-manufacturer grouping all but disappeared.

Vodafone attempted to reshape Japan's handset market by forging a new connection between the Japanese and global markets. It had reduced the number of its suppliers, promising NEC, Sanyo, and Toshiba that they could attain global scale by serving Vodafone's international markets. To this end, Vodafone abandoned J-Phone's previous lineup of proprietary Japanese standards with "global standard" handsets in 2002. However, to Japanese consumer these handsets appeared be a step backwards in functionality and usability. By 2004, Vodafone's Japan market share had slipped markedly, with a net subscriber loss.

A major wave of consolidation swept manufacturers. Until 2008, an astonishing eleven major Japanese firms provided handsets. By 2010, this had shrunk to five, with mergers between Kyocera and Sanyo, NEC, Casio and Hitachi, and Fujitsu and Toshiba, and the exit of Mitsubishi (see Table 3). These mergers followed several tie-ups in manufacturers' development processes, previously been atomized within each firm, as software development costs skyrocketed in tandem with greater handset sophistication. ${ }^{32}$

\subsection{Government orientation: aiming towards global markets}

As Japan's telecommunications markets grew increasingly isolated, with the opportunity costs of missing the Internet and rapidly expanding global cellular markets worldwide becoming clear, MIC began focusing on international competitiveness and global markets. While it had been careful to adopt global 3G standards in the late 1990s to avoid a repeat of the PDC standard driving isolation, it saw that proprietary market dynamics continued to isolate the domestic market. A ministry deliberation council first articulated the notion of

\footnotetext{
30 "Yuragu tsushingaisha yuui: shouhish shuyaku, kadenkei ga hiyaku [The swaying advantage in communications firms: consumers as the main character, household electronics manufacturers leaping ahead]." Nihon Keizai Shimbun. July 12, 2007. p. 13.

${ }^{31}$ Until then, handsets were only branded with the carrier, and a letter designation in the model number indicated the manufacturer.

${ }^{32}$ For example, KDDI began working with Toshiba, Sanyo, and Qualcomm to create a common operating system for handsets in its services. Until then, each manufacturer had been making its own software. The goal was to reduce R\&D costs for software to less than one third, since a majority of the estimated 10 to 20 million yen for developing a new handset was in software. This facilitated manufacturers who had not been supplying KDDI, such as Panasonic and NEC, to do so. "“au'keitai sofuto kyotsuka ['au' to facilitate common software.]" Nihon Keizai Shimbun. July 19, 2006.
} 
Table 2 Japanese handset manufacturers, 2006

\begin{tabular}{llll}
\hline & DoCoMo & KDDI & Vodafone \\
\hline Panasonic & $\mathrm{O}$ & $\mathrm{X}$ & $\mathrm{X}$ \\
NEC & $\mathrm{O}$ & $\mathrm{X}$ & $\mathrm{O}$ \\
Fujitsu & $\mathrm{O}$ & $\mathrm{X}$ & $\mathrm{X}$ \\
Sanyo & $\mathrm{O}$ & $\mathrm{O}$ & $\mathrm{X}$ \\
Sharp & $\mathrm{O}$ & $\mathrm{X}$ & $\mathrm{O}$ \\
Sony Ericsson & $\mathrm{O}$ & $\mathrm{O}$ & $\mathrm{X}$ \\
Toshiba & $\mathrm{X}$ & $\mathrm{O}$ & $\mathrm{O}$ \\
Casio & $\mathrm{X}$ & $\mathrm{O}$ & $\mathrm{X}$ \\
Hitachi & $\mathrm{X}$ & $\mathrm{O}$ & $\mathrm{X}$ \\
Kyocera & $\mathrm{X}$ & $\mathrm{O}$ & $\mathrm{X}$ \\
Mitsubishi & $\mathrm{O}$ & $\mathrm{O}$ & $\mathrm{X}$ \\
\hline
\end{tabular}

O indicates the manufacturer supplies that carrier, $X$ indicates it does not (adapted from Nikkei 7.19.2006)

"Galapagos" cellular markets in a 2007 report, and various policy initiatives were aimed at reshaping the domestic market to create a better fit with global markets (MIC 2007).

Some measures designed to increase the level of competition, however, actually ended up driving Japan's cellular market further along its proprietary trajectory. In October 2006, MIC implemented "number portability," enabling consumers to keep their telephone numbers after changing carriers. MIC's aim was to reduce the subscriber lock-in effect that deterred users from changing carriers. DoCoMo, with the largest subscriber base, was the major beneficiary of this lock-in. Carriers' responses were, however, to accelerate their development of proprietary features to create new lock-in effects. As the date for number portability approached, carriers engaged in a massive push towards electronic money, music players, thumbprint scans, ever high resolution cameras, and digital television broadcast receivers. As it turned out, widely used elements such as email addresses with carrierspecific domain names, data from various applications, song downloads, games, and other content were widely used, but not "portable." After a year, only 3\% of consumers took advantage of number portability ${ }^{33}$ - a sharp contrast to AT\&T Wireless of the US, which experienced an exodus of subscribers as soon as number portability was introduced in 2003 , leading to the carrier's rapid demise.

In 2007, MIC attempted explicitly to shift the dynamics of competition to better align them with international markets. MIC's deliberation council, the "Mobile Business Study Group," recommended that handset subsidies be abolished and SIM cards be "unlocked," allowing the same handset to work on different carriers. The experience of South Korea was raised, where a ban on handset subsidies led manufacturers to pursue international markets. ${ }^{34}$

Carriers reacted preemptively upon learning of this report. In late 2007, they announced new fee structures, offered in parallel to existing fee structures. Consumers could choose whether to pay higher communications fees and receive traditionally subsidized handsets, or pay slightly lower communication fees in exchange for lower

$\overline{33}$ (Keitai norikae 3\% todomari [Cell phone carrier shifting remains at 3\%] 2007)

${ }^{34}$ For details on the South Korean experience, see Kushida (2008) 
Table 3 Japanese handset manufacturers, 2010

\begin{tabular}{llll}
\hline & DoCoMo & KDDI & Softbank \\
\hline Panasonic & $\mathrm{O}$ & $\mathrm{O}$ & $\mathrm{O}$ \\
NEC Casio (absorbed Hitachi) & $\mathrm{O}$ & $\mathrm{O}$ & $\mathrm{O}$ \\
Fujitsu Toshiba & $\mathrm{O}$ & $\mathrm{O}$ & $\mathrm{O}$ \\
Sharp & $\mathrm{O}$ & $\mathrm{O}$ & $\mathrm{O}$ \\
Kyocera (absorbed Sanyo) & $\mathrm{X}$ & $\mathrm{O}$ & $\mathrm{X}$ \\
Sony Ericsson & $\mathrm{X}$ & $\mathrm{O}$ & $\mathrm{X}$ \\
\hline
\end{tabular}

$\mathrm{O}$ indicates the manufacturer supplies that carrier, $\mathrm{X}$ indicates it does not

subsidies and 2 year contracts. The resulting highly complex menu of fee structures and options bewildered consumers, and carriers avoided being forced to shift entirely to new fee structures. This contributed to a slowdown in handset turnover, but the advent of the iPhone and era of "smartphones" shifted the global trajectory of handsets before Japanese manufacturers could use the new domestic dynamics of competition to launch new international strategies.

\subsection{Residual leading without followers: NTT’s next generation network}

There are, however, still several residual threats of leading without followers in Japan's telecommunications markets. By far the most significant was NTT's "Next Generation Network" (NGN) strategy. From around 2006, NTT began heavily marketing its "Next Generation Network," commercializing it in 2008 to much (Japanese) media fanfare. The NGN consisted of an entirely new fiber network that replaced NTT's existing Internet backbone and network infrastructure. While the conventional Internet ran on the NGN, it offered several additional built-in features: VoIP with guarantees on throughput (Quality of Service) to allow high resolution video conferencing, security measures enabling data packet to be traced to their origin, and enhanced security for Virtual Private Networks for corporations. Both the upload and download speeds were between 100 and $160 \mathrm{Mbps}$.

Security and quality of service are serious concerns for the current Internet architecture, and NTT's strategy to was avoid becoming simply a commodity provider of Internet access by addressing these concerns at a network infrastructure level. NTT also planned to combine its various networks-conventional telephone, Internet backbone, and mobile-into the NGN. To this end, NTT invested approximately a fourth of its capital expenditures on NGN-in 2007 alone totaling 4.4 billion yen.

NTT's NGN was, however, not only proprietary to Japan, but it was also closed. Firms were required to sign contracts with NTT to offer applications or services taking advantage of NGN's enhanced features. The NGN was not allowed to become an open playground for experimentation in the manner of the Internet; it was intended as a platform for services and applications requiring high levels of security and reliability, such as healthcare, government, education, high resolution video conferencing, and Virtual Private Networks. By November 2008, however, the only commercial service introduced specifically for NGN was a video conferencing system from NEC, costing about $\$ 10,000$. Government strategies to implement new IT tools in these same areas of healthcare, government, and education refocused on "Cloud Computing" solutions, in which the sophistication is at the providers' datacenter rather than in the network - a different trajectory entirely from what NTT was 
pursuing (MIC 2010). ${ }^{35}$ Facing this decisive lack of enthusiasm, NTT quietly dropped its NGN marketing campaign emphasizing its special features, repositioning it simply as a high speed FTTH service.

\section{Conclusion}

This paper has explained Japan's persistent pattern of leading without followers in the telecommunications sector. It contends that competitive dynamics, shaped by the configuration of actors, the source of technological trajectories and business models, the patterns of intra-industry and government-business interactions, and the government's orientation towards international markets pushed Japan's telecommunications sector to ever higher levels of sophistication, even as it became decoupled from global markets. The configuration of these factors originated in the historical establishment of the sector, and political dynamics reshaped them over time (see Table 4). Japan's telecommunications isolation was not simply a product of proprietary standards, since even after it adopted global standards, the dynamics of competition kept the sector incompatible with global markets. It went deeper than simply misguided corporate strategies, since the dynamics of competition created a situation in which winning in the domestic market led to losing in global markets-what we might call the "Galapagos effect." And it is not an unambiguously negative narrative about government choices or strategies. While a richer analysis of the politics driving the key policies will be left to longer publications, this analysis has shown that political processes, at key junctures, which often trumped bureaucratic strategy, structured and restructured the actors and regulatory environment. The unintended consequences of these political outcomes led to the particular dynamics of competition that isolated the domestic market. Overall, this analysis breaks down notions of a monolithic policymaking logic, highlighting the complex interplay between the logic of politics and the interests of elite bureaucrats, with the resulting industry structures that shape competitive dynamics.

Japan's pattern of leading without followers is certainly a story of platforms. It reveals the importance of platform providers' international business strategies including the ability to bring complementary elements of the broader ecosystem abroad as well-in this case handsets and the content ecosystem. This observation goes beyond Japan, and transcends telecommunications, since most large service providers in a variety of sectors evolved from national contexts, and because services are generally greatly influenced by the rules, regulations, and social normative factors (Zysman et al. 2011).

This leads to a point about services versus products. When products are valuable only if coupled with particular services, then the logic of competition surrounding services will determine the competitiveness of products. When the logic of services competition cannot be carried beyond the domestic market, then products can become trapped. Apple, a new entrant without vested interests in existing services or communications products, solved this problem by integrating its own platform into its products, plowing through diverse national network services markets by commoditizing the network services on which its products and platforms run. ${ }^{36}$

The key factor in Japan's telecommunications sector is NTT with its vast resources, which drove much of Japan's pattern of leading without followers. The advent of the

\footnotetext{
${ }^{35}$ For an overview of Cloud Computing, see (Kushida 2011)

${ }^{36}$ For example, an iPhone or Android user cares about the functionality of their device and the services of the Apple App Store or Android App Market rather than functions provided by specific carriers-AT\&T, Verizon, or Softbank, for example.
} 


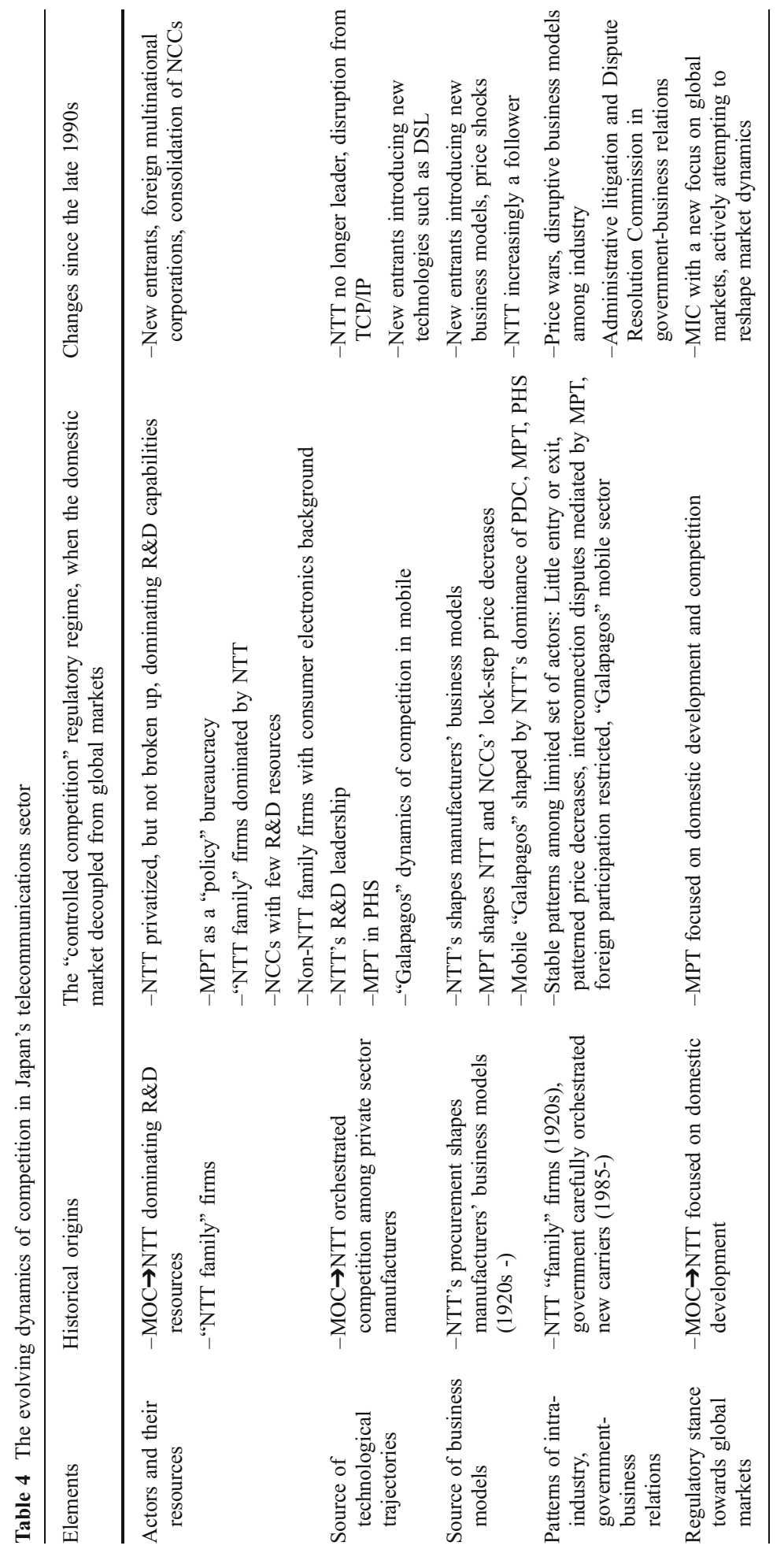


Internet was the beginning of NTT's loss of ability to set technological trajectories and business models. However, the transformation of Japan's telecommunications sector was not simply a story of technological inevitability-politics and regulatory shifts continued to shape the actors, technological possibilities, and business models. For example, deregulation by MPT, driven by the political logic within and surrounding the ministry, shaped the timing of new entrants. Quick regulatory support, by no means inevitable, aided specific technologies and business models such as DSL and VoIP.

The story of leading without followers is also not simply about too much or too little government intervention. The "controlled competition" regulatory regime did end up isolating the market, but Japanese citizens benefited from their advanced domestic market, and were willing to pay for advanced services. Moreover, without regulatory protections in the initial phase of liberalization, NTT could easily have engaged in predatory pricing to decimate all new NCCs. Japan's case also shows that tightly managed markets are not inherently detrimental to rapid development. The broader lesson, however, is that strategy should focus not only on fostering domestic competition, but also on shaping international linkages that help shape technological trajectories. Catching up along existing technological trajectories is the primary challenge for most late developers, but once caught up, the new challenge is not only how to stay ahead, but how to stay ahead along the right trajectory. This requires a different type of strategy-how to set trajectories-to avoid the real risk of becoming a leader without followers. This is a potentially fruitful area for future research regarding China and other rapidly developing economies, particularly those considered fast followers.

Finally, while this study reinforces the notion of global competition as national developments springing onto a global stage, it highlights a particular dilemma facing localities. If domestic markets become too decoupled from global markets, then even if they become highly developed, they cannot spring onto the global stage - the "Galapagos effect." However, if the domestic market is so open that it can only follow external trajectories, this weakens its ability for distinctive competitive advantages to gestate in the domestic market before bursting into global markets. The search for balance between distinctive advantages through local resources versus becoming a permanent follower is a central challenge for advanced industrial countries. Japan's experience of becoming a leader without followers is extreme, but it's very extremity brings into sharp relief these issues facing nations, regions, and industries worldwide. Future research can examine causes and means to avoid a similar situation, along with the "Galapagos effect" in broad and diverse regulatory and sectoral contexts.

Open Access This article is distributed under the terms of the Creative Commons Attribution Noncommercial License which permits any noncommercial use, distribution, and reproduction in any medium, provided the original author(s) and source are credited.

\section{References}

Anchordoguy M (2001) Nippon Telegraph and Telephone Company (NTT) and the building of a telecommunications industry in Japan. Bus Hist Rev 75:507-541

Barma N, Vogel SK (2008) The political economy reader: markets as institutions. Routledge, New York

Beck J, Wade M (2003) Japan's wireless tsunami, how one mobile telecom created a new market and became a global force. AMACOM, New York, NY

Berger S, Dore RP (1996) National diversity and global capitalism. Cornell University Press, Ithaca, NY 
Cole RE (2006) Telecommunications markets in world markets: understanding Japan's decline. In: Zysman J, Newman A (eds) How revolutionary was the digital revolution?: national responses, market transitions, and global technology. Stanford University Press, Stanford, CA, pp 101-124

DoCoMo N (2001) NTT DoCoMo junenshi: Mobairu furontia e no chousen [NTT DoCoMo 10 year history: the challenge towards mobile frontier]. NTT DoCoMo, Tokyo, Japan

Esping-Andersen G (1990) The three worlds of welfare capitalism. Princeton University Press, Princeton, NJ

Fligstein N (2001) The architecture of markets: an economic sociology of twenty-first-century capitalist societies. Princeton University Press, Princeton, NJ

Fransman M (1995) Japan's computer and communications industry: the evolution of industrial giants and global competitiveness. Oxford University Press, New York, NY

Fuke H (2000) Joho Tsushin Sangyo no Kozo to Kisei Kanwa: Nchibeiei Hikaku Kenkyuu. (Structural Change and Deregulation in the Telecommunications Industry). NTT Shuppan, Tokyo

Funk J (2001) The mobile internet: how Japan dialed up and the west disconnected. ISI Publications, Kent, UK

Funk J (2002) Global competition between and within standards: the case of mobile phones. Palgrave New York, NY

Funk JL (2004) Mobile disruption: the technologies and applications driving the mobile Internet. WileyInterscience, Hoboken, NJ

Hall P, Soskice D (2001) An introduction to varieties of capitalism. In: Hall P, Soskice D (eds) Varieties of capitalism: the institutional foundations of comparative advantage. Oxford University Press, New York, NY

Ida T (2009) Broadband economics: lessons from Japan. Routledge, New York

Johnson C (1989) MITI, MPT, and the Telecom Wars: how Japan makes policy in high technology. In: Johnson C, Tyson L, Zysman J (ed) Politics and productivity: how Japan's developmental strategy works. Harper Business

Kawabata E (2006) Contemporary government reform in Japan: the dual state in flux. Palgrave Macmillan, New York

Keitai Denwa: Sony, Docomo muke tettai [Cellular phones: Sony withdrawing from supplying DoCoMo] (2008) Nihon Keizai Shimbun, March 10, p 1

Keitai norikae 3\% todomari [Cell phone carrier shifting remains at 3\%] (2007) Nihon Keizai Shimbun, October 22, p 7

Kenney M, Pon B (2011) Structuring the Smartphone Industry: Is the Mobile Internet OS Platform the Key? doi:10.1007/s10842-011-0105-6.

Kitschelt H (1991) Industrial Governance Structures, Innovation Strategies, and the Case of Japan: Sectoral or Cross-National Comparative Analysis? International Organization Vol 45 (4):453-493.

Kushida K (2006) Japan's telecommunications regime shift: understanding Japan's potential resurgence. In: Newman A, Zysman J (eds) How revolutionary was the digital revolution? National responses, market transitions, and global technology in the digital era. Stanford University Press, Stanford, CA

Kushida KE (2005) The politics of restructuring NTT: historically rooted trajectories from actors, institutions, and interests Stanford. J East Asian Aff 5(2):29-36

Kushida KE (2008) Wireless bound and unbound: the politics shaping cellular markets in Japan and South Korea. J Inf Technol Polit 5(2):231-254

Kushida KE (2010) Inside the castle gates: how foreign firms navigate Japan's policymaking processes. Doctoral Dissertation, University of California Berkeley, Berkeley, CA

Kushida KE (2011) Entrepreneurship in Japan's telecommunications sector: opportunities and protection from regulatory structures. Paper presented to Stanford project on Japanese entrepreneurship conference. Stanford, CA

Kushida KE, Ogata M (2007) When innovators and not implementors: the political economies of voip in the U.S. and Japan. BRIE Working Paper 180

Kushida KE, Oh S-Y (2007) The political economies of broadband in South Korea and Japan. Asian Surv 47 (3):481-504

Kushida KE, Zysman J (2009) The services transformation and network policy: the new logic of value creation. Rev Policy Res 26(1-2):173-194

Masuno D (2006) Gyoukai Kenkyu Shiriizu: Tsushin [Industry Analysis Series: Telecom]. Nihon Keizai Shimbun Sha, Tokyo, Japan

MIC (2007) ICT kokusai kyousouryoku kondankai saishuu torimatome [ICT international competitiveness deliberation council final report] Ministry of Internal Affairs and Communications. http://www.soumu. go.jp/menu_news/s-news/2007/pdf/070423_1_1.pdf. Accessed 1 Feb 2010

MIC (2010) Smaato Kuraudo Senryaku, Chukan Matome [Preliminary Report on the Smart Cloud Strategy]. Ministry of Internal Affairs and Communications. http://www.soumu.go.jp/menu_news/s-news/ 02ryutsu02_000023.html. Accessed 1 Feb 2010 
Mitsuyama N (2003a) NTT DoCoMo: I-mode wireless internet services. Gartner Research

Mitsuyama N (2003b) NTT DoCoMo: I-mode wireless internet services. Gartner

Murase E (2003) Keitai Boomu: the case of NTT Docomo and innovation in the wireless internet in Japan. Stanford University, Stanford, CA

NikkeiCommunications (ed) (2005) Fuunji Tachi ga Makiokosu Keitai Denwa Houkai no Jokyoku: Shirarezaru Tsushin Sensou no Shinjitsu [The opening tune of the destruction of the cellular phone order, brought about by adventurers: the truth of the telecommunications wars revealed]. Nikkei BP, Tokyo

Parker A (2010) Sony Ericsson on mission to gain US share. Financial Times (February 14)

Polanyi K (1944) Great transformation: the political and economic origins of our time. Beacon, Boston, MA

Prasirtsuk K (2001) Reluctant liberalization: domestic networks and trade policy demands in Japan. Dissertation, University of California Berkeley, Berkeley, CA

Ratliff JM (2002) NTT DoCoMo and its i-mode success: origins and implications. Calif Manage Rev 44 (3):55-71

Schaede, U. (2011) Show me the money: Japan's most profitable firms in the 2000s. Working Paper. http:// irps.ucsd.edu/assets/001/500973.pdf

Sorkin AR (2009) Too big to fail: the inside story of how Wall Street and Washington fought to save the financial system from crisis-and themselves. Viking, New York

Suzuki T, Kamio H, Tanaka J (2005) Gyakuten Senryaku: Uirukomu "Yowami” wo "tsuyomi” ni kaeru ishi no keiei [Reversal Strategy: Wilcom, management will shifting weakness to strength]. Diamondo Sha, Tokyo, Japan

Tanaka T, Murakami R (2003) Network externalities in the Japanese market of routers. Competition Policy Research Center Discussion Paper, Fair Trade Commission of Japan (1-E)

Tett G (2009) Fool's gold: how the bold dream of a small tribe at J.P. Morgan was corrupted by Wall Street greed and unleashed a catastrophe. 1st Free Press hardcover edn. Free Press, New York

Vogel SK (1996) Freer markets, more rules: regulatory reform in advanced industrial countries. Cornell University Press, Ithaca, NY

Vogel SK (2000) Creation competition in Japan's telecommunications markets. Japan Information Access Project Working Paper

Vogel SK, Zysman J (2002) Technology. In: Vogel SK (ed) U.S.-Japan relations in a changing world. Brookings Institution Press, Washington, D.C, pp 239-261

Yamamura K, Streeck W (2003) The end of diversity?: prospects for German and Japanese capitalism. Cornell University Press, Ithaca, NY

Yuasa I (2000) NTT DoCoMo no Chousen [NTT DoCoMo’s Challange]. Koushobou, Tokyo

Zysman J (1983) Governments, markets, and growth: financial systems and the politics of industrial change. Cornell University Press, Ithaca, NY

Zysman J (2006) Creating value in a digital era: how do wealthy nations stay wealthy? In: Zysman J, Newman A (eds) How revolutionary was the digital revolution?: national responses, market transitions, and global technology. Stanford University Press, Stanford, CA

Zysman J, Feldman S, Murray J, Kushida KE (2011) Services with everything: the digital transformation of services from economic Sinkhole to Productivity Driver. BRIE Working Paper 187a 